\title{
Oral mucosal foreign body granulomas in a patient with systemic sarcoidosis
}

\author{
Ole Kristian Lobekk, ${ }^{1}$ Anne Christine Johannessen, ${ }^{2}$ Torbjørn $\varnothing$ Pedersen $~^{3}{ }^{3}$
}

${ }^{1}$ Faculty of Medicine, University of Bergen, Bergen, Norway ${ }^{2}$ Department of Pathology, Haukeland University Hospital, Bergen, Norway ${ }^{3}$ Department of Maxillofacial Surgery, Haukeland University Hospital, Bergen, Norway

\section{Correspondence to} Dr Torbjørn $\varnothing$ Pedersen; Torbjorn.Pedersen@uib.no

Accepted 26 August 2020

\section{DESCRIPTION}

A 46-year-old woman with biopsy-verified pulmonal sarcoidosis presented with submucosal noduli of the lower lip (figure 1). The noduli had, according to the patient, first appeared 6 months earlier. The lip was tender to traumatic biting and varied in size. The lesion and nearby small salivary glands were removed and the histopathological examination showed noncaseating granulomas in the connective tissue and underlying salivary glands. In several of the granulomas in the connective tissue, polarisable foreign bodies could be observed (figure 2). The patient had 4 years earlier, before the onset of her sarcoidosis, been involved in a bicycle accident where she fell into a pile of stone dust. Due to the characteristics of the histopathological findings, the submucosal noduli of the lower lip was diagnosed as foreign body granulomas, possibly induced by her systemic sarcoidosis.

Cutaneous foreign bodies are generally considered to exclude the diagnosis of

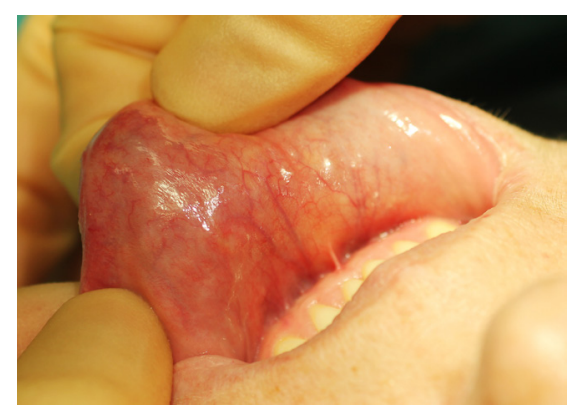

Figure 1 Submucosal noduli of the lower lip were registered with well-vascularised but intact overlying mucosa.

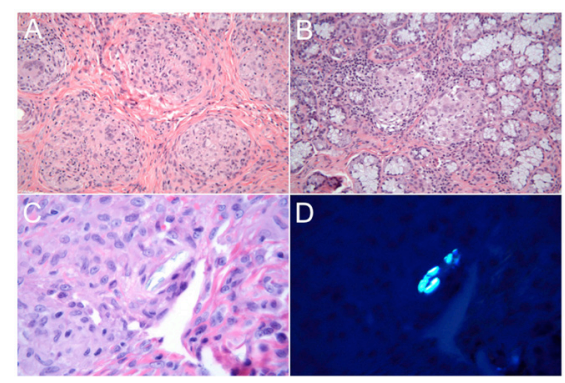

Figure 2 Histopathological examination showed non-caseating granulomas in the connective tissue $(A)$ and underlying salivary glands (B). In several of the granulomas in the connective tissue, polarisable foreign bodies could be observed (C, D).

\section{Patient's perspective}

The onset of my symptoms started following the bicycle accident where I injured my face and aspirated stone dust. I was bothered by the hard mass that developed in my lip, and was glad to have it removed.

\section{Learning points}

- Trauma to the oral mucosa can induce mucosal foreign body granulomas in patients with systemic sarcoidosis.

- Oral mucosal foreign body granulomas have similar histopathological features as cutaneous lesions.

sarcoidosis. However, patients with sarcoidosis have a predilection for formation of granulomas also following trauma to the skin, and cutaneous foreign bodies have been described in patients with systemic sarcoidosis. ${ }^{1}$ The excessive immune response found in sarcoidosis can be in response to particulate foreign material, and the distribution pattern may be correlated to a higher presence of exogenous material in the lungs or skin compared with other organs. ${ }^{2}$ Oral manifestations are rarely encountered, ${ }^{3}$ and in this patient, trauma to the lip likely induced formation of non-caseating foreign body granulomas of the oral mucosa due to her underlying systemic sarcoidosis.

Contributors OKL treated the patient, drafted the manuscript and approved the final version. ACJ performed histological evaluations, reviewed and edited the manuscript and approved the final version. TØP drafted and edited the manuscript and approved the final version.

Funding The authors have not declared a specific grant for this research from any funding agency in the public, commercial or not-for-profit sectors.

Competing interests None declared.

Patient consent for publication Obtained.

Provenance and peer review Not commissioned; externally peer reviewed.

ORCID iD

Torbjørn Ø Pedersen http://orcid.org/0000-0001-9463-3076

\section{REFERENCES}

1 Kim YC, Triffet MK, Gibson LE. Foreign bodies in sarcoidosis. Am J Dermatopathol 2000;22:408-12.

2 Walsh NM, Hanly JG, Tremaine R, et al. Cutaneous sarcoidosis and foreign bodies. Am J Dermatopathol 1993;15:203-7. 
Copyright 2020 BMJ Publishing Group. All rights reserved. For permission to reuse any of this content visit https://www.bmj.com/company/products-services/rights-and-licensing/permissions/

BMJ Case Report Fellows may re-use this article for personal use and teaching without any further permission.

Become a Fellow of BMJ Case Reports today and you can:

- Submit as many cases as you like

- Enjoy fast sympathetic peer review and rapid publication of accepted articles

- Access all the published articles

- Re-use any of the published material for personal use and teaching without further permission

Customer Service

If you have any further queries about your subscription, please contact our customer services team on +44 (0) 2071111105 or via email at support@bmj.com. Visit casereports.bmj.com for more articles like this and to become a Fellow 